\title{
HARMONISASI PEMBALIKAN BEBAN PEMBUKTIAN TINDAK PIDANA KORUPSI
}

\author{
A Djoko Sumaryanto \\ Fakultas Hukum Universitas Bhayangkara Surabaya \\ djokosumaryanto67@gmail.com
}

\begin{abstract}
This legal research is carried out aimed at finding a common ground and meeting point of reversing the burden of proof to obtain clarity, firmness, and legal certainty and not to violate human rights. The system of reversing the burden of proof of corruption is proof beyond the norm of the evidence system in Indonesia, besides that the application of the reversal of the burden of proof tends to violate human rights (HAM). This legal research uses the normative legal research method with a statutory approach and a conceptual approach. The results of the study concluded that between the legislation resulting from the ratification Act has a different character, so that the reversal of the burden of proof needs to be harmonized so that in its implementation there is no overlapping.
\end{abstract}

Keywords: Corruption; Harmonization; Proof.

\begin{abstract}
Abstrak
Penelitian hukum ini dilakukan bertujuan untuk mencari suatu kesamaan dan titik temu dari pembalikan beban pembuktian agar diperoleh kejelasan, ketegasan, dan kepastian hukum serta tidak melanggar HAM. Sistem pembalikan beban pembuktian tindak pidana korupsi merupakan pembuktian diluar kelaziman sistem pembuktian di Indonesia, disamping hal tersebut penerapan pembalikan beban pembuktian cederung melanggar hak asasi manusia (HAM). Penelitian hukum ini menggunakan metode penelitian hukum normative dengan pendekatan Perundang-undangan (Statute Approach) dan pendekatan konsep (Conseptual Approach). Hasil penelitian menyimpulkan bahwa antara undang-undang hasil legislasi dengan Undang-undang hasil ratifikasi memiliki karakter yang berbeda-beda, sehingga pembalikan beban pembuktian perlu dilakukan harmonisasi, agar dalam pelaksanaannya tidak terjadi tumpang tindih (overlapping).
\end{abstract}

Kata Kunci: Harmonisasi; Korupsi; Pembuktian.

\section{PENDAHULUAN}

Pemberantasan korupsi merupakan masalah paling mendesak yang harus dilakukan di tanah air karena telah secara signifikan menghambat kemajuan bangsa. Kebiasaan korupsi terlihat begitu besar dan di luar kontrol pemerintah. Akan tetapi langkah untuk memberantas korupsi ini sering terhalang berbagai masalah yang kompleks. Namun semua elemen bangsa harus bisa menghentikan praktek tercela tersebut. Memberantas korupsi adalah tugas berat, namun bukan berarti tidak mungkin untuk dilakukan.

Konsideran (menimbang) dari UU 31/1999 tentang Pemberantasan Tindak Pidana Korupsi menyatakan bahwa Tindak Pidana Korupsi sangat merugikan keuangan negara atau perekonomian negara dan menghambat pembangunan nasional, dan akibat tindak

A Djoko Sumaryanto, Harmonisasi Pembalikan Beban Pembuktian Tindak Pidana Korupsi. 
Supremasi Hukum : Jurnal Penelitian Hukum

p-ISSN: 1693-766X ; e-ISSN: 2579-4663, Vol. 28, No. 2, Agustus 2019, 108-122

pidana korupsi yang terjadi selama ini selain merugikan keuangan negara atau perekonomian negara, juga menghambat pertumbuhan dan kelangsungan pembangunan nasional yang menuntut efisiensi tinggi.

Korupsi sudah terjadi pada semua bidang tata pemerintahan, baik eksekutif, legislatif maupun yudikatif. Daniel Kaufmann ${ }^{1}$ dalam laporan mengenai bureucratie and judicial bribery menyatakan praktek penyuapan di peradilan di Indonesia merupakan yang tertinggi diantara negara-negara berkembang. Disinyalir tidak sedikit hakim di semua tingkatan peradilan yang melakukan Korupsi. Akibat integritas yang rendah dan kemampuan terbatas dari hakim ini menyebabkan banyak putusan pengadilan dalam kasus korupsi yang tidak mencerminkan rasa keadilan masyarakat.

Upaya pengembalian aset harus terus dilakukan oleh Pemerintah Indonesia. Alasannya, pertama, berdasarkan data kerugian keuangan negara sebagaimana telah diuraikan dimuka, sangat tepat menyebutkan Indonesia sebagai negara korban korupsi ; kedua, dana atau aset yang dikorupsi tersebut adalah harta kekayaan negara Indonesia yang harus diperuntukkan bagi pembangunan dalam upaya meningkatkan kemakmuran dan kesejahteraan rakyat Indonesia. Tindak pidana korupsi telah mengakibatkan hilangnya kesempatan rakyat Indonesia untuk menikmati hak-haknya dan menempatkan sebagian besar rakyat hidup di bawah garis kemiskinan ; ketiga, negara memiliki kewajiban untuk melindungi dan menciptakan kesejahteraan bagi rakyatnya melalui pencapaian alternatif sumber pendanaan. Salah satu sumber pendanaan tersebut harus diambil dari dana atau aset hasil tindak pidana korupsi ; keempat, upaya pengembalian aset memiliki makna preventif terletak pada pengungkapan kepada publik bahwa tidak ada tempat yang aman di dunia bagi para pelaku tindak pidana korupsi. Sedangkan makna represif terletak pada pemidanaan para pelaku tindak pidana korupsi ; Kelima, Indonesia telah meratifikasi United Nation Convention Against Corruption 2003 (UNCAC) melalui Undang-undang Nomor 7 tahun 2006 tentang Konvensi Anti Korupsi (UU KAK), sehingga tersedia landasan hukum untuk melaksanakan kerja sama Internasional dalam upaya pengembalian aset hasil tindak pidana korupsi

Doktrin hukum pidana dan konvensi Internasional mengenai perlindungan hak asasi manusia tidak mengakui pembuktian terbalik untuk menentukan kesalahan tersangka. Namun, pembuktian terbalik untuk menetapkan perampasan aset tindak pidana. Sejak tahun 2000 telah dipraktekkan dalam sistem hukum perampasan aset tindak pidana di Amerika Serikat melalui sarana hukum keperdataan (civil based forfeitture/NCB). Lazimnya, sejak lama diakui sistem hukum perampasan aset tindak

${ }^{1}$ Daniel Kaufmann, Governance and Corruption : New Empirical Fortier For Program Design, dalam T Mulya Lubis, Reformasi Hukum Anti Korupsi, Makalah disampaikan dalam Konferensi Menuju Indonesia Bebas Korupsi, Depok, 18 September 1998

A Djoko Sumaryanto, Harmonisasi Pembalikan Beban Pembuktian Tindak Pidana Korupsi. 
Supremasi Hukum : Jurnal Penelitian Hukum

p-ISSN: 1693-766X ; e-ISSN: 2579-4663, Vol. 28, No. 2, Agustus 2019, 108-122

pidana (criminal based forfeiture/CB) yang dilaksanakan berdasarkan putusan pengadilan yang telah memperoleh kekuatan hukum tetap. ${ }^{2}$

Model perampasan aset NCB dengan pembuktian terbalik tidak melanggar HAM karena didasarkan pada teori balanced probability principle, yang memisahkan antara aset tindak pidana dan pemiliknya. Hal ini didasarkan premis bahwa perlindungan hak terdakwa untuk dianggap tidak bersalah (presumption of innocent) dan prinsip non-self incrimination harus diimbangi kewajiban terdakwa membuktikan asal-usul aset yang dimilikinya. Teori ini masih memberikan jaminan perlindungan hak asasi tersangka untuk dianggap tidak bersalah, sebaliknya tidak memberikan jaminan perlindungan hak kepemilikan terdakwa atas aset yang diduga berasal dari tindak pidana, kecuali yang bersangkutan dapat membuktikan sebaliknya. ${ }^{3}$

Meski banyak usulan, pertanyaan yang bernada kegamangan tetap terlontar, apakah memang kejahatan luar biasa (extra ordinary crime) ini nantinya benar-benar bisa dibongkar dengan mengandalkan pembuktian terbalik, atau bisakah pembuktian terbalik dijadikan senjata ampuh untuk mengalahkan dan menciptakan "horor" dikalangan koruptor ? atau bisakah koruptor dihentikan atau dihambat akselerasi aksiaksinya dengan pembuktian terbalik?.

Jika mengingat pembuktian terbalik bisa diandalkan menjerat, mempertanggungjawabkan, dan mengalahkan koruptor atau mampu menjadi ruh bekerjanya sistem peradilan pidana (criminal justice system), sistem pembuktian terbalik wajib diberlakukan lebih dahulu pada elemen penegak hukum seperti jaksa, hakim, polisi, KPK, dan lembaga-lembaga strategis yang menjadi pilar bekerjanya law enforcement. 4

Peraturan perundang-undangan positif tentang pemberantasan korupsi dituntut untuk dapat menyesuaikan dengan KAK 2003, supaya dengan konsistensi dalam peraturan perundang-undangan tidak akan terjadi kebingungan atau pengertian yang bias terhadap penafsiran norma yang ada oleh aparat penegak hukum. Juga disampaikan beberapa tulisan tentang pembalikan beban pembuktian, yaitu Edwin Adiabakti, dkk 5 dengan judul Disharmonisasi Pengaturan Pembalikan Beban Pembuktian Perkara Pidana dalam Perundang-undangan di Indonesia, dalam tulisan ini penulis menyatakan terjadi ketidakharmonisan dalam pembalikan beban pembuktian pada beberapa undang-undang yaitu Korupsi, Pencucian uang, perlindungan konsumen

\footnotetext{
${ }^{2}$ Romli Atmasasmita, "Dilema Pembuktian Terbalik", Kompas, 4 Pebruari 2011, hlm 6

${ }^{3}$ Ibid

${ }_{4}$ Mariadi dalam Misranto, Koruptor Membalik Pembuktian Terbalik, Media Indonesia, Selasa 5 April 2011, hlm. 15

5 Erwin Adiabakti, Masruchin Ruba'I, Yuliati, Disharmoni Pengaturan Pembalikan Beban Pembuktian Perkara Pidana dalam Perundang-undangan di Indonesia, https://media.neliti.com/media/publications/118349-ID-disharmonisasi-pengaturan-pembalikanbeb.pdf, diunduh tanggal 29 maret 2019, pukul 14.00.
}

A Djoko Sumaryanto, Harmonisasi Pembalikan Beban Pembuktian Tindak Pidana Korupsi. 
Supremasi Hukum : Jurnal Penelitian Hukum

p-ISSN: 1693-766X ; e-ISSN: 2579-4663, Vol. 28, No. 2, Agustus 2019, 108-122

dan lingkungan hidup. Hasnawati ${ }^{6}$ dengan judul Pembalikan Beban Pembuktian dalam Tindak Pidana Korupsi di Indonesia, dalam tulisan ini penulis menyatakan bahwa dalam pembalikan beban pembuktian tindak pidana korupsi terhadap harta benda pelaku dan perbuatan pelaku dengan terbatas dan berimbang, serta Mulyanto $\mathbf{7}$ dengan judul Praktek Pembatasan Pembalikan Beban Pembuktian dalam Pengadilan Tipikor (Studi pada Perkara Korupsi RAPBD Kota Semarang di Pengadilan Tipikor Kota Semarang) bahwa dalam penelitian terhadap putusan pengadilan negeri semarang tersebut, tidak terjadi pembalikan beban pembuktian dikarenakan perbuatannya adalah tindak pidana suap dan tidak terjadi kerugian keuangan negara.

Tulisan ini bertujuan memfokuskan pada perspektif yang lain yaitu harmonisasi pembalikan beban pembuktian tindak pidana korupsi yang merupakan kajian terhadap undang-undang tindak pidana korupsi hasil legislasi (UU PTPK) dengan undang-undang hasil ratifikasi (UU KAK 2003) sehingga dengan perbedaan kajian terhadap Pembalikan Beban Pembuktian maka membuat tulisan ini menjadi tulisan yang berbeda. Berdasarkan uraian latar belakang tersebut disusun rumusan masalah sebagai berikut : (1) Bagaimana sistem pembalikan beban pembuktian dalam perundang-undangan tindak pidana korupsi diluar Konvensi Anti Korupsi ?; (2) Bagaimana harmonisasi sistem pembalikan beban pembuktian dalam perundangan-undangan tindak pidana korupsi ?

\section{METODE PENELITIAN}

Metode penelitian yang dipergunakan dalam penulisan ini adalah dengan menggunakan tipe penelitian hukum normative, dengan menggunakan dua pendekatan yaitu pendekatan perundang-undangan (statute approach) yang mengkaji norma dalam tindak pidana korupsi yang menggunakan pembalikan beban pembuktian dan pendekatan konsep (conceptual approach) yang mengkaji mengenai konsep pembalikan beban pembuktian, dan hasil pembahasan dijelaskan dalam suatu analisis (deskriptif analisis) .

\section{HASIL DAN PEMBAHASAN}

\section{Sistem Pembalikan Beban Pembuktian tindak pidana korupsi diluar UU KAK}

Pembalikan beban pembuktian (Omkering van het Bewishlash/Reversal burden of proof) merupakan pembuktian yang diluar kelaziman dalam hukum acara pidana di Indonesia. Hukum acara pidana yang diterapkan dalam pembuktian tindak pidana korupsi dengan menggunakan Undang-undang Nomor 8 tahun 1981 tentang Kitab

${ }^{6}$ Hasnawati, Pembalikan Beban Pembuktian dalam Tindak Pidana Korupsi di Indonesia, https://media.neliti.com/media/publications/148267-ID-pembalikan-beban-pembuktian-dalamtindak.pdf, di Unduh tanggal 29 Maret 2019, pukul 14.15.

${ }^{7}$ Mulyanto, Praktik Pembatasan Pembalikan Beban Pembuktian dalam Pengadilan Tipikor, journals.ums.ac.id/index.php/jurisprudence/article/download/3009/1951, diUnduh tanggal 29 Maret 2019, pukul 14.20

A Djoko Sumaryanto, Harmonisasi Pembalikan Beban Pembuktian Tindak Pidana Korupsi. 
Supremasi Hukum : Jurnal Penelitian Hukum

p-ISSN: 1693-766X ; e-ISSN: 2579-4663, Vol. 28, No. 2, Agustus 2019, 108-122

Undang-undang Hukum Acara Pidana (KUHAP) (sebagai Lex Generali) dan Undangundang Nomor 31 tahun 1999 tentang Pemberantasan Tindak Pidana Korupsi (UU PTPK) (sebagai Lex Specialis), Artinya pembuktian tindak pidana korupsi dapat dilakukan dengan pembuktian biasa dan pembuktian terbalik antara keduanya memiliki perbedaan, yaitu mengenai cara pembuktiannya dan alat bukti yang digunakan. Tentang cara membuktikan pembuktian biasa caranya menggunakan alat-alat bukti menurut KUHAP tanpa kecuali, ialah membuktikan semua unsur-unsur tindak pidana dengan menggunakan alat-alat bukti yang mengacu pada syarat minimal pembuktian. 8 Teori pembuktian yang selama ini diakui adalah "pembuktian negatif" sesuai Pasal 183 KUHAP yang menuntut pembuktian "beyond Reasonable Doubt" dan sejalan dengan prinsip praduga tak bersalah (presumption of Innocence) yang sering menyulitkan proses pembuktian kasus-kasus korupsi.

Menurut UUPTPK pembalikan beban pembuktian memiliki 2 (dua) karekter, yaitu apabila berkenaan dengan perbuatannya, menurut Pasal 37 ayat (1) UU PTPK bahwa "terdakwa mempunyai hak untuk membuktikan bahwa ia tidak melakukan tindak pidana korupsi" artinya apabila terdakwa menggunakan haknya untuk membuktikan perbuatannya bukan tindak pidana korupsi maka berlakulah pembalikan beban pembuktian yang terbatas dan berimbang, dan apabila terdakwa tidak menggunakan haknya maka tidak terjadi pembalikan beban pembuktian (pembuktian conventional) Sedangkan menurut Pasal 37 A ayat (1) UU PTPK menyatakan bahwa "terdakwa wajib memberikan keterangan tentang seluruh harta bendanya dan harta benda istri atau suami, anak dan harta benda setiap orang atau korporasi yang diduga mempunyai hubungan dengan perkara yang didakwakan" artinya terhadap harta benda terdakwa berlakulah pembaikan beban pembuktian yang terbatas dan berimbang antara penuntut umum dengan terdakwa atau penasehat hukum terdakwa.

Sistem pembuktian terbalik yang berimbang cara pembuktiannya disamping menggunakan alat-alat bukti seperti dalam KUHAP, Jaksa dapat menggunakan hasil pembuktian terdakwa atau Penasehat hukum. 9 Apabila terdakwa tidak berhasil membuktikan tentang keseimbangan antara sumber pendapatannya dengan harta bendanya, maka ketidakberhasilannya itu digunakan Jaksa Penuntut Umum (JPU) untuk memperkuat dari alat bukti yang sudah ada.

Mengenai alat bukti yang digunakan terdapat perbedaan yaitu pembuktian biasa sesuai Pasal 184 KUHAP, bahan atau alat bukti yang digunakan untuk membentuk alat bukti petunjuk seperti keterangan saksi, surat dan keterangan terdakwa (Pasal 188 ayat (2) KUHAP), juga informasi dan dokumen yang disebutkan dalam Pasal 26 A UU PTPK. Sedangkan sistem pembuktian terbalik berimbang yaitu sesuai Pasal 184 KUHAP Lebih

\footnotetext{
${ }^{8}$ Vide Pasal 183 Undang-undang Nomor 8 Tahun 1981 tentang KUHAP

${ }^{9}$ Vide Pasal 37 A ayat (2) Undang-undang Nomor 31 tahun 1999 jo Undang-undang Nomor 20 tahun 2001 tentang Perubahan Undang-undang Nomor 31 tahun 1999 tentang Pemberantasan Tindak Pidana Korupsi (UU PTPK)
}

A Djoko Sumaryanto, Harmonisasi Pembalikan Beban Pembuktian Tindak Pidana Korupsi. 
Supremasi Hukum : Jurnal Penelitian Hukum

p-ISSN: 1693-766X ; e-ISSN: 2579-4663, Vol. 28, No. 2, Agustus 2019, 108-122

luas dari pada sistem pembuktian biasa, misalnya : Keterangan saksi yang tidak disumpah (Pasal 185 ayat (7), JPU dapat menggunakan hasil pembuktian terdakwa yang tidak dapat membuktikan tentang sumber yang halal dari sebagian atau seluruh harta bendanya.

Berkaitan dengan pembalikan beban pembuktian pada tindak pidana pencucian uang menurut Undang-undang nomor 8 tahun 2010 tentang tindak pidana pencucian uang (money laundering) (UU TPPU), Pasal 77 UU TPPU menjelaskan bahwa "Untuk kepentingan pemeriksaan di sidang pengadilan, terdakwa wajib membuktikan bahwa harta kekayaannya bukan merupakan hasil tindak pidana" (garis bawah dari penulis). Sedang menurut Pasal 78 ayat (1) UU TPPU pada intinya "hakim memerintahkan terdakwa agar membuktikan bahwa harta kekayaan yang terkait dengan perkara bukan berasal atau terkait dengan tindak pidana sebagaimana dimaksud dalam Pasal 2 ayat (1) "(garis bawah dari penulis).

Kata "wajib" seperti yang tertuang pada Pasal 77 UU TPPU dimaksudkan bahwa terdakwa berkewajiban untuk membuktikan harta kekayaannya itu bukan berasal dari tindak pidana seperti yang tertuang pada Pasal 2 ayat (1) UU TPPU juga Pasal 2 ayat (2) yang merupakan perluasan dari Pasal 2 ayat (1) huruf $\mathrm{n}$, tentang tindak pidana terorisme. Sedangkan kata "Hakim memerintahkan terdakwa agar membuktikan" sesuai yang tertuang dalam Pasal 78 ayat (1) UU TPPU menurut penulis hal ini merupakan otoritas hakim dalam memeriksa perkara tindak pidana pencucian uang disamping terdakwa wajib, pada pasal ini lebih keras lagi hakim memerintahkan kepada terdakwa untuk membuktikan, hal ini merupakan bentuk pembuktian yang dipaksakan oleh peradilan kepada terdakwa, yang tujuannya untuk mendapat kejelasan akan status harta kekayaan milik terdakwa.

Untuk pertamakalinya dalam sejarah peradilan pidana, pembuktian terbalik diterapkan. Itulah yang terjadi pada perkara Bahasyim Assifie, mantan pejabat pajak, yang pada tanggal 2 Pebruari 2011, Pengadilan Negeri Jakarta Selatan memvonis Bahasyim Assifie dengan hukuman 10 (sepuluh) tahun penjara, pidana denda Rp. 250 juta (subsider tiga bulan kurungan). Pengadilan memerintahkan agar harta kekayaan Bahasyim senilai Rp. 61 miliar dan US\$ 681.153 disita untuk negara.

Menurut majelis hakim yang diketuai Didik Setyo Handono, Bahasyim Assifie terbukti menerima suap, Bahasyim dinyatakan melanggar Pasal 11 UU 20/2001 tentang Pemberantasan Tindak Pidana Korupsi. Bahasyim juga dinyatakan melanggar Pasal 3 ayat (1) UU 15/2002 tentang Tindak Pidana Pencucian Uang (Money Laundering). Putusan perkara Bahasyim Assifie akan amat berarti bagi upaya pemberantasan korupsi, lantaran proses penanganan perkara tersebut menggunakan "pembuktian terbalik" (Pembalikan Beban Pembuktian).

Teori pembalikan beban pembuktian yang dianut oleh UU 31/1999 jo UU 20/2001 adalah merupakan beban pembuktian yang diberikan kepada terdakwa atau penasihat hukumnya untuk membuktikan bahwa terdakwa tidak bersalah namun demikian

A Djoko Sumaryanto, Harmonisasi Pembalikan Beban Pembuktian Tindak Pidana Korupsi. 
Supremasi Hukum : Jurnal Penelitian Hukum

p-ISSN: 1693-766X ; e-ISSN: 2579-4663, Vol. 28, No. 2, Agustus 2019, 108-122

penuntut umum tetap berkewajiban membuktikan kesalahan terdakwa, beban pembuktian semacam ini disebut pembalikan beban pembuktian yang bersifat berimbang. Sebagaimana dimaksudkan Pasal 37, 37 A UU 31/1999 jo UU 20/2001. Pasal 37 menyatakan bahwa "Terdakwa mempunyai hak untuk membuktikan bahwa ia tidak melakukan tindak pidana korupsi"(garis bawah oleh penulis), karena merupakan hak maka tergantung terdakwa, apakah akan menggunakan haknya atau tidak. Sedangkan Pasal 37 A menyatakan bahwa " Terdakwa wajib memberikan keterangan tentang seluruh harta bendanya dan harta benda istri atau suami, anak, dan harta benda setiap orang atau korporasi yang diduga mempunyai hubungan dengan perkara yang bersangkutan" (garis bawah oleh penulis). Karena wajib, maka terdakwa wajib membuktikan harta bendanya, caranya ialah membuktikan adanya keseimbangan antara harta bendanya dengan sumber penghasilannya atau sumber penambahan kekayaannya.

Pembalikan beban pembuktian yang berkenaan dengan pengembalian kerugian keuangan negara adalah keterangan terdakwa dalam membuktikan bahwa harta bendanya bukan berasal dari tindak pidana korupsi. Keberhasilan terdakwa membuktikan tentang harta benda yang didakwakan sebagai harta yang halal, karena sumbernya atau sumber tambahan kekayaannya berupa sumber yang halal, tidak akan berpengaruh apapun terhadap pembuktian Penuntut Umum mengenai perkara pokok, apabila penuntut umum memang berhasil membuktikan tentang unsur-unsurnya dan terbukti terdakwa bersalah melakukannya

Apabila terdakwa tidak berhasil membuktikan sumber penghasilan yang seimbang dengan kekayaannya atau tidak terbukti sumber kekayaan itu adalah sah/halal, maka penuntut umum dapat menggunakan keadaan yang demikian untuk memperkuat alat bukti yang sudah ada bahwa terdakwa bersalah melakukan tindak pidana korupsi, dan apabila terdakwa berhasil membuktikan keseimbangan itu, berarti harta benda yang didakwakan tidak ada hubungannya dengan Tindak pidana yang didakwakan dan harta benda tersebut tidak dapat dirampas (dijatuhkan Pidana perampasan barang) untuk negara.

Pada sistem beban pembuktian biasa berlaku cara menggunakan alat-alat bukti menurut KUHAP tanpa kecuali, ialah membuktikan semua unsur tindak pidana dengan menggunakan alat-alat bukti yang mengacu pada syarat minimal pembuktian dalam Pasal 183 KUHAP. Sedangkan pada sistem beban pembuktian semi terbalik, disamping cara menggunakan alat-alat bukti sebagaimana yang diatur dalam KUHAP, Penuntut Umum dapat menggunakan hasil pembuktian terdakwa dan atau Penasihat hukumnya menurut Pasal 37 A ayat (2) UU PTPK, apabila terdakwa tidak berhasil membuktikan tentang keseimbangan antara sumber pendapatannya atau penambahan kekayaannya dengan harta bendanya, maka keadaan ketidakberhasilan itu digunakan oleh Penuntut Umum untuk memperkuat dari alat bukti yang sudah ada untuk menghasilkan

A Djoko Sumaryanto, Harmonisasi Pembalikan Beban Pembuktian Tindak Pidana Korupsi. 
Supremasi Hukum : Jurnal Penelitian Hukum

p-ISSN: 1693-766X ; e-ISSN: 2579-4663, Vol. 28, No. 2, Agustus 2019, 108-122

kesimpulan pembuktian bahwa terdakwa telah melakukan tindak pidana korupsi seperti yang didakwakan.

Berbeda dengan pembuktian terhadap tindak pidana gratifikasi (gratification). Gratifikasi (gratification) merupakan istilah baru yang diintroduksi dalam UndangUndang pemberantasan tindak Pidana Korupsi Pasal 12 B dan Pasal 12 C UU 20/2001. Rumusan tentang gratifikasi yang mengatur tentang ancaman pidana adalah penerima gratifikasi bukan pemberi gratifikasi, ini artinya tindak pidana gratifikasi berbeda dengan tindak pidana Suap (penyuap dan yang disuap sama-sama bisa dipidana). Artinya, bahwa menjadi tindak pidana gratifikasi apabila penerima tidak melaporkan penerimaan tersebut kepada KPK dalam kurun waktu 30 (tiga puluh) hari, bukan pada pemberi (gratifikasi).

Pasal 12 b Undang-Undang 20 Tahun 2001 juga mengatur tentang sistem pembuktian Tindak Pidana Gratifikasi yaitu pembalikan beban pembuktian yang mutlak (Absolute Reversal burder of proof), yang berbeda dengan pembalikan beban pembuktian yang bersifat terbatas dan berimbang (Reversal Burden of Proof) seperti pada Tindak Pidana Korupsi, juga dengan sistem pembuktian biasa (Conventional) seperti yang diatur oleh KUHAP. Pembalikan beban pembuktian yang mutlak adalah pembalikan beban pembuktian dari system pembuktian negative (negative wettelijk) yang menjadi beban / tanggung jawab dari penuntut umum menjadikan beban pembuktian bagi penerima gratifikasi terhadap gratifikasi yang diterimanya (terbatas dan berimbang), apabila nilainya kurang dari 10 (sepuluh) juta rupiah, dan menjadi tanggungjawab penerima gratifikasi saja apabila nilainya diatas 10 (sepuluh) juta rupiah (mutlak).

\section{Sistem Pembalikan Beban Pembuktian menurut UU KAK}

Menurut UU KAK 2003, Sistem pembalikan beban pembuktian terdapat dalam Pasal 31 ayat (8) dan Pasal 53 huruf (b). Secara tegas ketentuan pembalikan beban pembuktian dalam KAK 2003 ditujukan terhadap pembekuan, perampasan dan penyitaan harta benda pelaku tindak pidana korupsi. Pasal 31 ayat (8) KAK 2003 menyebutkan, bahwa : "States parties may consider the possibility of requiring that an offender demonstrade the lawful origin of alleged proceedsof crime or other property liable to conviscation, to the extent that such a requirement is consistent whit fundamental principles of their domestic law and with the nature of judicial and other proceedings.

Ketentuan di atas menentukan negara-negara peserta konvensi dapat mempertimbangkan kemungkinan untuk mewajibkan seorang pelanggar menerangkan sumber yang sah atas hasil-hasil yang diduga berasal dari tindak pidana atau kekayaan lainnya yang dapat dikenakan penyitaan, sejauh syarat tersebut konsisten dengan prinsip-prinsip dasar hukum nasional, dan konsisten pula dengan sifat dari proses yudisial dan proses peradilan lainnya.

Selain ketentuan Pasal 31 ayat (8) UU KAK 2003, pembalikan beban pembuktian juga diatur dalam ketentuan Pasal 53 huruf b, yang secara tegas menentukan bahwa :

A Djoko Sumaryanto, Harmonisasi Pembalikan Beban Pembuktian Tindak Pidana Korupsi. 
Supremasi Hukum : Jurnal Penelitian Hukum

p-ISSN: 1693-766X ; e-ISSN: 2579-4663, Vol. 28, No. 2, Agustus 2019, 108-122

"Mengambil tindakan-tindakan yang mungkin diperlukan untuk mengizinkan pengadilan-pengadilan memerintahkan orang-orang yang telah melakukan kejahatankejahatan yang ditetapkan berdasarkan konvensi ini untuk membayar kompensasi atau ganti rugi kepada Negara peserta yang lain yang telah dirugikan oleh kejahatankejahatan tersebut".

Ketentuan konteks di atas merupakan pembalikan beban pembuktian terhadap pengembalian aset secara langsung dengan memberi izin kepada pengadilan negara setempat memerintahkan kepada pelaku tindak pidana korupsi untuk membayar kompensasi atau ganti rugi kepada negara lain yang dirugikan akibat dari tindak pidana korupsi tersebut.

Dalam pembalikan beban pembuktian tindak pidana korupsi asset/uang masih berada pada terdakwa sehingga dalam putusan hakim disamping menjatuhkan pidana penjara, pidana denda, juga pidana tambahan berupa mengembalian kerugian keuangan Negara sejumlah asset/uang yang telah terbukti dalam persidangan.

Kalimat kunci dalam Pasal 31 ayat (8) UU KAK 2003 adalah menggugat hak kepemilikan seseorang atas harta kekayaannya yang berasal dari tindak pidana korupsi. Rumusan pasal tersebut memang bersifat "non-mandatory obligation" sehingga penerapannya sangat tergantung dari sikap dan komitmen politik pemerintah dan sistem hukum nasional yang dianut oleh negara pihak yang bersangkutan. Dalam konteks sistem hukum pidana Indonesia yang telah berlaku dimana pembuktian terbalik telah dimuat dalam ketentuan Pasal 37 UU PTPK dan Pasal 37 UU TPPU (money laundering), maka ketentuan pasal 31 ayat (8) UU KAK 2003 telah memperkuat kembali pemberlakuan teori "pembuktian terbalik" dalam hal menyangkut harta kekayaan seorang tersangka.

Pemberlakuan sistem pembuktian terbalik terhadap asset hasil kejahatan termasuk korupsi juga telah diatur dalam ketentuan "proceed of crime act"tahun 2002 (POCA 2002). POCA 2002 telah menetapkan strategi baru yang disebut "Asset Recovery Strategy". Strategi ini dalam pandangan House of Lord The Privy Council dan pengadilan eropa itu sendiri menegaskan bahwa tidak bertentangan dengan asas praduga tak bersalah. POCA 2002 mengutamakan proses pembuktian terbalik melalui proses keperdataan (civil recovery).

\section{Harmonisasi Pembalikan Beban Pembuktian Tindak Pidana Korupsi}

Suatu hal yang mudah dipahami ketika essensi prinsip sebuah negara hukum dan prinsip pemerintahan berdasarkan sistem konstitusi yang ditegaskan dalam UUD 1945 menghendaki adanya suatu sistem hukum, yakni setiap norma hukum harus terkait dan tersusun dalam suatu sistem, artinya norma hukum yang satu tidak boleh bertentangan atau mengesampingkan norma hukum yang lain. Dalam kerangka sistem hukum nasional, semua peraturan perundang-undangan dipandang sebagai satu sistem yang utuh, konsistensi, harmonisasi dan terintegrasi dalam tata urutan peraturan

A Djoko Sumaryanto, Harmonisasi Pembalikan Beban Pembuktian Tindak Pidana Korupsi. 
Supremasi Hukum : Jurnal Penelitian Hukum

p-ISSN: 1693-766X ; e-ISSN: 2579-4663, Vol. 28, No. 2, Agustus 2019, 108-122

perundang-undangan, dan penegakan hukum akan mampu menentukan kadar kepastian hukum. Pada gilirannya kepastian hukum akan menjadi perhatian dan pengamatan masyarakat, karena masyarakat memiliki perasaan peka terhadap ketidakadilan.

Pemikiran harmonisasi bermula dari Rudolf Stammler yang mengemukakan bahwa konsep dan prinsip-prinsip hukum yang adil mencakup "harmonisasi" antara maksud, tujuan, dan kepentingan individu dengan maksud, tujuan dan kepentingan masyarakat umum. Dengan kata lain, hukum akan tercipta baik apabila terdapat keselarasan antara maksud, tujuan dan kepentingan penguasa (pemerintah) dengan masyarakat.

Wacito Setiadi 10 mengatakan ada 3 alasan atau fungsi Harmonisasi hukum, yaitu : 1) untuk menjaga keselarasan, kemantapan, dan kebulatan konsepsi peraturan perundang-undangan sebagai sistem dengan tujuan peraturan tersebut dapat berfungsi secara efektif, 2) sebagai upaya prefentif dalam rangka mencegah diajukannya permohonan judicial review peraturan perundang-undangan kepada kekauasaan kehakiman yang kompeten, dan 3) menjamin proses pembentukan peraturan perundang-undangan dilakukan secara taat asas hukum demi kepentingan dan kepastian hukum ada sebagian diskursus mengenai pemberantasan korupsi, frase kata "pembalikan beban pembuktian" senantiasa diajukan sebagai suatu metode dan prasyarat meningkatkan upaya dan hasil pemberantasan korupsi. Untuk itu, perlu diajukan beberapa prasyarat dan diintegrasikan dalam suatu sistem pemberantasan korupsi yang tepat agar pembalikan beban pembuktian dapat benar-benar efektif.

Undang-undang Pemberantasan Tindak Pidana korupsi mengatur Pembalikan Beban Pembuktian yang berhubungan dengan 2 (dua) hal, yaitu pertama, pembuktian terbalik yang berhubungan dengan penentuan salah tidaknya seseorang yang disangka atau didakwa melakukan tindak pidana korupsi (vide Pasal 37 ayat (1) dan (2) UU PTPK). Kedua, pembuktian terbalik yang berhubungan dengan penentuan keabsahan atas kepemilikan harta kekayaan seseorang yang disangka atau didakwa dihasilkan dari tindak pidana korupsi (vide Pasal 37 ayat (3) dan (4) UU PTPK.

Kedua ketentuan pembuktian terbalik diatas, belum pernah dilaksanakan dalam proses persidangan di pengadilan, hakim belum pernah secara eksplisit meminta terdakwa untuk membuktian bahwa dirinya tidak bersalah. Ketentuan ini hanya dilaksanakan secara implisit, karena terdakwa atau penasehat hukumnya selalu diberi kesempatan untuk menyampaikan pembelaan diri (pledoi), dimana terdakwa atau penasehat hukumnya pada umumnya selalu menyatakan bahwa terdakwa tidak bersalah.

${ }^{10}$ Wacipto Setiadi, Proses Pengharmonisasian Sebagai Upaya Untuk Memperbaiki Kualitas Peraturan Perundang-Undangan, Jurnal Legislatif Indonesia Vol.4 No.2, Juni 2007, p.48

A Djoko Sumaryanto, Harmonisasi Pembalikan Beban Pembuktian Tindak Pidana Korupsi. 
Supremasi Hukum : Jurnal Penelitian Hukum

p-ISSN: 1693-766X ; e-ISSN: 2579-4663, Vol. 28, No. 2, Agustus 2019, 108-122

Pemberlakuan pembuktian terbalik sering dianggap bertentangan dengan prinsip-prinsip hukum acara dan perlindungan terhadap hak tersangka/terdakwa. Dalam perkara korupsi (UU PTPK dan UU KAK 2003) "pembuktian terbalik" sudah mulai diterapkan. Hal tersebut menunjukkan bahwa sistem "pembuktian terbalik" tidak bertentangan dengan asas-asas hukum acara dan perlindungan hak tersangka/terdakwa. Antara lain:

Asas Praduga tak Bersalah, merupakan suatu prinsip fundamental atas hak untuk mendapatkan pengadilan yang adil adalah hak bagi setiap orang yang didakwa telah melakukan tindak pidana untuk dianggap tidak bersalah menurut putusan hakim yang berkekuatan tetap (incrach van gewisde). Penerapan pembuktian terbalik nampaknya bertentangan dengan asas praduga tak berslah, karena memberikan beban pembuktian kepada terdakwa. Namun pembuktian terbalik yang diatur dalam Pasal 37 ayat (1) dan (2) UU PTPK hanya merupakan hak bukan kewajiban terdakwa. Ketentuan ini justru memberikan hak kepada terdakwa untuk membela diri bukan memberikan kewajiban beban pembuktian, dan penuntut umum tetap berkewajiban untuk membuktian tindak pidana korupsi yang didakwakan.

Berkenaan dengan Pasal 37 ayat (3) dan (4) UU PTPK juga tidak bertentangan dengan asas praduga tak bersalah, dimana terdakwa dianggap tidak bersalah sehingga tidak mendapatkan beban pembuktian terhadap unsur tindak pidana korupsi yang didakwakan. Pembuktian terbalik bukan memberikan beban pembuktian kepada terdakwa untuk membuktikan salah-tidaknya terdakwa terhadap unsur-unsur tindak pidana korupsi yang didakwakan. Terdakwa hanya berkewajiban untuk membuktikan tentang sah atau tidaknya sumber harta kekayaan yang dimilikinya. Hasil pembuktian yang disampaikan juga bukan sebagai alat bukti untuk menyatakan salah-tidaknya terdakwa, melainkan hanya memperkuat alat bukti yang sudah ada.

Hak untuk tidak dipaksa mengakui kesalahan, sesuai dengan anggapan tidak bersalah, maka tersangka/terdakwa memiliki hak untuk tidak dipaksa memberikan kesaksian sendiri untuk mengaku salah. Asas ini dipandang sebagai cerminan asas akusator (accusatoir), dimana terdakwa diberlakukan sebagai pihak dalam proses pidana. Pasal 14 ayat (3) huruf g Kovenan Internasional tentang Hak-hak Sipil dan Politik, yang telah diratifikasi dengan UU No. 12 Tahun 2005, menyebutkan bahwa dalam penentuan tuduhan pelanggaran pidana terhadapnya, setiap orang berhak untuk tidak dipaksa memberikan kesaksian terhadap diri sendiri atau mengaku bersalah. Sedangkan menurut Pasal 52 KUHAP menyebutkan bahwa "dalam pemeriksaan pada tingkat penyidikan dan pengadilan, tersangka/terdakwa berhak memberikan keterangan secara bebas kepada penyidik dan hakim". Penjelasannya mengatakan, supaya pemeriksaan dapat mencapai hasil yang tidak menyimpang dari pada yang sebenarnya, maka tersangka/terdakwa harus dijauhkan dari rasa takut. Oleh karena itu, wajib dicegah adanya paksaan atau tekanan terhadap tersangka/terdakwa.

A Djoko Sumaryanto, Harmonisasi Pembalikan Beban Pembuktian Tindak Pidana Korupsi. 
Supremasi Hukum : Jurnal Penelitian Hukum

p-ISSN: 1693-766X ; e-ISSN: 2579-4663, Vol. 28, No. 2, Agustus 2019, 108-122

Pembuktian terbalik tidak dimaksudkan untuk memaksa terdakwa untuk memberikan kesaksian atau pengakuan salah. Pembuktian terbalik justru menempatkan terdakwa untuk memberikan pembuktian bahwa yang bersangkutan tidak bersalah sebagaimana didakwakan oleh penuntut umum atau menyampaikan bukti bahwa kepemilikan harta kekayaan yang dimilikinya didapatkan dengan cara yang sah. Dengan demikian pembuktian terbalik tidak dapat dikatakan bertentangan dengan hak terdakwa untuk tidak dipaksa memberikan kesaksian dan mengakui kesalahan.

Hak kepemilikan individu, pembuktian terbalik terhadap hak kepemilikan harta kekayaan seseorang yang diduga berasal dari korupai menimbulkan pro dan kontra. Pandangan kontra mengatakan bahwa pembuktian terbalik dalam hal kepemilikan harta kekayaan tersebut bertentangan dengan hak asasi manusia, yaitu setiap orang berhak untuk memperoleh kekayaannya dan hak privasi yang harus dilindungi.

Kepemilikan seseorang terhadap harta kekayaannya memang diakui dijamin oleh peraturan perundang-undangan, namun kepemilikan individu tersebut bukan merupakan hak yang mutlak (absolute) seperti hak atas kemerdekaan, hak untuk hidup, hak untuk memperoleh peradilan yang adil, dan hak-hak lainnya. Kepemilikan individu terhadap harta kekayaannya sering disebut dengan hak relative, karena disamping harta kekayaan itu menjadi milik individu, masih ada kepentingan umum yang menjadi tanggung jawab negara.

Bertolak dari pemikiran bahwa korupsi merupakan kejahatan transnasional dan menjadi sumber kemiskinan bangsa, maka kepemilikan harta kekayaan seseorang didapat dari hasil yang sah tidak dianggap bertentangan dengan hak kepemilikan individu. Pembuktian terbalik menjadi sarana hukum yang diharapkan dapat efektif untuk mengembalikan uang negara yang dibawa oleh koruptor dengan cara tidak sah. Hak kepemilikan individu atas harta kekayaannya tetap diakui dan dijamin sepanjang dihasilkan dengan cara-cara yang benar dan sah menurut hukum yang berlaku.

Pelaksanaan pembuktian terbalik harus mengacu pada peraturan perundangundangan yang ada dengan tetap memperhatikan konstitusi negara Indonesia (UUD 1945) yang mengatur tentang hak asasi manusia, antara lain : Pasal 28 D ayat (1) yang menetapkan bahwa setiap orang berhak atas pengakuan, jaminan, perlindungan, dan kepastian hukum yang adil serta perlakuan yang sama dihadapan hukum, demikian juga dengan Pasal $28 \mathrm{G}$ ayat (1) menetapkan bahwa setiap orang berhak atas perlindungan diri pribadi, keluarga, kehormatan, martabat, dan harta benda yang dibawah kekuasaannya, serta berhak atas rasa aman dan perlindungan dari ancaman ketakutan untuk berbuat atau tidak berbuat sesuatu yang merupakan hak asasi, dan Pasal $28 \mathrm{H}$ ayat (4) bahwa setiap orang berhak mempunyai hak milik pribadi dan hak milik tersebut tidak boleh diambil alih secara sewenang-wenang oleh siapapun. Oleh sebab itu menurut penulis prosedur pemberlakuan pembuktian terbalik kepada terdakwa, khususnya kasus tindak pidana korupsi harus melalui mekanisme

A Djoko Sumaryanto, Harmonisasi Pembalikan Beban Pembuktian Tindak Pidana Korupsi. 
Supremasi Hukum : Jurnal Penelitian Hukum

p-ISSN: 1693-766X ; e-ISSN: 2579-4663, Vol. 28, No. 2, Agustus 2019, 108-122

penuntutan yang wajar, artinya tidak seorangpun serta merta dijadikan tersangka dan didakwa melakukan korupsi tanpa disertai alat bukti yang akurat dan meyakinkan.

\section{PENUTUP \\ Simpulan}

Pengaturan terhadap sistem pembalikan beban pembuktian pada tindak pidana korupsi telah diatur secara jelas baik melalui Undang-undang pemberantasan tindak pidana korupsi (UU 3/1971, UU 31/1999 jo UU 20/2001 maupun UU 7/2006) dalam pelaksanaan pembalikan beban pembuktian dalam penyelesaian kasus korupsi ada yang merupakan kewajiban tersangka/terdakwa terutama berkenaan asal-usul harta kekayaan dari tersangka/terdakwa dan ada yang merupakan hak terdakwa terutama berkenaan dengan perbuatannya. Selanjutnya harmonisasi sistem pembalikan beban pembuktian terhadap peraturan perundang-undangan baik yang merupakan hasil legislasi (UU 31/1999 jo UU 20/2001) maupun hasil ratifikasi (UU 7/2006) seharusnya tidak melanggar hak asasi manusia, hal ini sangat diperlukan dalam rangka pembentukan paraturan perundang-undangan yang melindungi hak asasi manusia.

\section{Saran}

Dari simpulan di atas, diberikan saran yaitu pertama, sistem pembalikan beban pembuktian tindak pidana korupsi di Indonesia agar dibuat rumusan yang jelas, baik berkenaan dengan pembuktian harta benda tersangka/terdakwa dan pembuktian terhadap perbuatan tindak pidana korupsi. Kedua, berkenaan dengan peraturan perundang-undangan baik legislasi maupun ratifikasi harus selalu dilakukan harmonisasi, terutama sistem yang mengatur pembalikan beban pembuktian agar memiliki kepastian hukum, jelas, tegas, adil, dan mudah dilaksanakan, serta tidak melanggar hak asasi manusia.

\section{DAFTAR PUSTAKA}

Atmasasmita, Romli, 2007. Model Ampuh untuk Mengejar Aset Hasil Kejahatan Terhadap Negara, Newsletter KHN, Vol 7 (2) Maret-April.

--------------, Romli, 2011, “Dilema Pembuktian Terbalik”, Harian Kompas, 4 Pebruari.

Erwin Adiabakti, Masruchin Ruba'I, Yuliati, 2019 Disharmoni Pengaturan Pembalikan Beban Pembuktian Perkara Pidana dalam Perundang-undangan di Indonesia, https://media.neliti.com/media/publications/118349-ID-disharmonisasi-pengaturanpembalikan-beb.pdf, diunduh tanggal 29 Maret.

Harjowidigdo, Rooseno, 2007, Pembuktian Terbalik Harus dilalui melalui Mekanisme Penuntutan yang Wajar, Newsletter KHN, Vol 7 (2) Maret-April.

A Djoko Sumaryanto, Harmonisasi Pembalikan Beban Pembuktian Tindak Pidana Korupsi. 
Supremasi Hukum : Jurnal Penelitian Hukum

p-ISSN: 1693-766X ; e-ISSN: 2579-4663, Vol. 28, No. 2, Agustus 2019, 108-122

Hasnawati, Pembalikan Beban Pembuktian dalam Tindak Pidana Korupsi di Indonesia, 2019 https://media.neliti.com/media/publications/148267-ID-pembalikan-bebanpembuktian-dalam-tindak.pdf, di Unduh tanggal 29 Maret

Kartayasa, Mansur, 2016, Korupsi dan pembuktian terbalik, dari perpektif kebijakan legislasi dan hak asasi manusia, Penerbit : Gramedia Prenada Media Group

Mulyadi, Lilik, 2007, Pembalikan Beban Pembuktian Tindak Pidana Korupsi, Bandung, Penerbit : Alumni.

Misranto, 2011, Koruptor Membalik Pembuktian Terbalik, Media Indonesia, 5 April

Mulyanto, 2019, Praktik Pembatasan Pembalikan Beban Pembuktian dalam Pengadilan Tipikor, journals.ums.ac.id/index.php/jurisprudence/article/download/3009/1951, , diunduh tanggal 29 Maret.

Projohamidjojo, Martiman, 2001, Penerapan Pembuktian Terbalik dalam Delik Korupsi, Penerbit : Mandar Maju

Purwaning M Yanuar, 2007, Pengembalian Aset Hasil Korupsi (Berdasarkan Konvensi PBB Anti Korupsi 2003 Dalam Sistem Hukum Indonesia, Bandung, Penerbit : Alumni

Senoadji, Indriyanto, 2007, Delik Pembuktian Terbalik Tidak Dikenal di Negara Kontinental, Newsletter KHN, Vol 7 (2) Maret-April.

Sumaryanto, A Djoko, 2009, Pembalikan Beban Pembuktian Tindak Pidana Korupsi Dalam Rangka Pengembalian Kerugian Keuangan Negara, Jakarta, Penerbit : Prestasi Publiser.

Suardi Sabda, Yoseph, 2007. Sistem Pembuktian Terbalik Memang Diperlukan di dalam Praktek, Newsletter KHN, Vol 7 (2) Maret-April.

Sumaryanto, A Djoko, 2010, Sistem Pembalikan Beban Pembuktian (kajian terhadap tindak pidana korupsi dan tindak pidana pencucian uang/money laundering), Jurnal Perpektif Hukum, Vol. 10 (2) November.

Undang-undang Nomor : 8 Tahun 1981 tentang Kitab Undang-undang Hukum Acara Pidana (KUHAP)

A Djoko Sumaryanto, Harmonisasi Pembalikan Beban Pembuktian Tindak Pidana Korupsi. 
Supremasi Hukum : Jurnal Penelitian Hukum

p-ISSN: 1693-766X ; e-ISSN: 2579-4663, Vol. 28, No. 2, Agustus 2019, 108-122

Undang-undang Nomor 31 tahun 1999 tentang Pemberantasan Tindak Pidana Korupsi

Undang-undang Nomor 20 Tahun 2001 tentang Perubahan Undang-undang Nomor 31 tahun 1999 tentang pemberantasan Tindak Pidana Korupsi

Undang-undang Nomor 8 Tahun 2010 tentang Tindak Pidana Pencucian Uang (money Laundering)

Undang-undang Nomor 7 tahun 2006 tentang Pengesahan United Nation Convation Againts Corruption 2003 (UNCAC).

Wacipto Setiadi, 2007, Proses Pengharmonisasian Sebagai Upaya Untuk Memperbaiki Kualitas Peraturan Perundang-Undangan, Jurnal Legislatif Indonesia Vol.4 (2).

A Djoko Sumaryanto, Harmonisasi Pembalikan Beban Pembuktian Tindak Pidana Korupsi. 